Dominique Hecq, Christine Hill and Stephen Theiler

\title{
Looking for excellence: A comparative review of the splintering of the Arts and the Sciences
}

\begin{abstract}
This is a story that brings together excellence, research, poets, and scientists to explore their relationships and possible meanings. We examine the requirement for 'excellence in research' in an attempt to understand how this is defined, measured and justified, and we wonder if it is possible, meaningful, or even desirable in its current form. We ask if excellence in the Arts and the Sciences is a product or a process, or both. A snapshot of the historical development of the art/science divide leads us to challenge the usefulness of this dichotomy and to conclude that research excellence is poorly served by existing measures. The story unfolds like a Deleuzean map where art and science have the potential to trace each other in a process that creatively evaluates and modifies that thing we call knowledge. Keywords: excellence-research, knowledge production, creative process, Arts and Sciences
\end{abstract}

\section{Prologue}

On a Paris afternoon in June the poet and the physician reach Le jardin du Luxembourg. They make their way through alleys bordered with Cambridge bells, petunias and peonies. A breeze bites a little sharply. Sunlight glows through a canopy of clouds. The water on the pond ruffles and rustles.

Children race miniature colour-coated sailing boats. They slide, not in file, but buoyant disarray, yet gliding one by one among excited cries. They float, almost serenely past the two figures seated on a bench, their histories bracketed out in note-taking.

What is it you are writing, the poet asks,

it looks like Greek. So it is.

I mean, I could see that, but how do you relate it

to this walk, this sight... Interesting question.

Interesting doesn't mean much, does it?

The physicist keeps writing or drawing or doodling, a wry smile secured on his face, oblivious to the children at the edge of thepond and now to the beggars who seem to appear from nowhere.

A Tunisian asks for two Euros and the poet gives him chocolates instead and as he leaves he says 'Merci, mes enfants' - and sothey feel, the physicist and the poet, and call out for theirs.

They tuck their diminutive notebooks into their breast-pockets and make their way back as the conversation keeps erupting into incontrollable laughter. 


\section{Introduction}

Once upon a time the business of a university was education. Tertiary education, at its best, provided a sort of transitional space, between secondary school and adulthood, where wild ideas could be exchanged, tested, and refined - or rejected and replaced - in a supportive environment filled with people whose main job was to nurture thinking. Much has changed. We now live in a world where the role of the university is to produce research and, like the businesses they have become, universities must compete to survive. An outsider, trying to make sense of this, could be forgiven for viewing research as a strange competitive sport with complicated rules, numerous obstacles, and an unreliable umpire. Some insiders in the field of science (unpublished interviews) quite openly refer to research as a 'game' where they can play, and test their skills; others, like British academic, Lisa Lucas (2006) worry about a research game that focuses on winners and losers rather than on knowledge creation. Higher education staff and students in both art and science may well ask: Is this a game worth playing?

This paper considers the current rules of the game and how they might relate to excellence. To understand how these rules came about we take a brief but telling journey backwards, surveying the evolution of art and science, to unearth patterns and clues. This then enables us to look forwards, beyond the status quo, to imagine more meaningful ways to do research and to recognize excellence.

In the context of the Excellence in Research for Australia (ERA) scheme, the question of how to define and measure excellence has immediate consequences for the creative arts. Australia trialled the ERA exercise in 2009 and rolled it out across all university disciplines in 2010. New Zealand's Performance-Based Research Fund (PBRF) and the United Kingdom's Research Excellence Framework (REF) formerly the Research Assessment Exercise (REA) are also applied nation-wide.

Although different nations take different approaches to their research assessment exercises, ranking is a common feature. For example, New Zealand follows the UK and ranks individual researchers while Australia ranks Fields of Research Codes (FoRs) in Universities. These research evaluations are now well entrenched in the university sector and their ranking measures tend to side-line the arts. Further, as some critiques suggest (Bonnell 2014, Larkins 2012), such major, government-initiated policy changes will most certainly dictate the way national and international institutions think about research, recruitment and promotion, to the detriment of the creative arts as well as arts practitioners, especially if their work is experimental, or innovative.

The focus of the Australian ERA exercise is the measurement of research 'quality', 'excellence' and even 'eminence', as the most recentpromotions guidelines at our university reveal. In 2012, Gerry Turcotte and Robyn Morris warned that, as soon as measurements are invoked, debates about the instruments and mechanisms used to produce and interpret the data inevitably dominate (Turcotte \& Morris 2012: 66), and indeed, questions about both, and about the viability of a national research measurement system, abound in the media. These debates are also pursued in academic journals, conferences and seminars, and have been for some time. During a two-day seminar in September 2009, the National Academics Forum (NAF) scrutinised the accuracy, impact, strengths and weaknesses, long-term and short-term effects on the publishing and research behaviour of Australian researchers and publishers. Two key issues of debate arising from this seminar concerned the reliability of using bibliometrics as a measurement system for academic output, and the contentious 'eligible' journal list compiled by the Australian Research Council (ARC). This list assigned each journal a discipline code and a ranking. A vigorous debate arose, leading to the abolishment of the levels of ranking. Whilst rankings no longer apply, they are etched in our memories. And in case we forget, journals such as TEXT still refer to rankings on their front page.

It is the issue of excellence that is most contentious; one that impacts negatively upon the creative arts, as is the case at our university in its attempt to become recognised as a 
research-intensive institution capable of competing for research funding. Furthermore, the development of ERA as the latest government research quality framework has coincided with the inclusion of the creative industries on the Federal Government's development of a proposed national high school curriculum and attendant workshops by the Australian Curriculum, Assessment and Reporting Authority, 'an independent statutory authority that will improve the learning of all young Australians through world-class school curriculum, assessment and reporting' (ACARA 2013).

Creative writers, increasingly embedded in whole or in part within universities, have struggled for some time to have their outputs acknowledged by a 'measurement' system that was designed for sciences, imperfectly modified, and applied to the arts and humanities; it appeared that the creative industries don't count! Or can they? In 2015, ERA's aim 'to identify and promote excellence across the full spectrum of research activity in Australia's higher education institutions' (ERA 2015) has led to some changes that allow a space for the creative arts. Nevertheless, a broad understanding and interpretation of excellence will be essential to relieve the lingering anxiety among academics and postgraduate students who know that quality does not necessarily foster 'recognition' - at least immediate recognition, let alone produce financial returns.

\section{Definitions}

What do we really mean by 'excellence'?

A Latin Dictionary (Andrews 1879) gives us 'excellentia, superiority, excellence, perfection' (675) and, over a century later, the French dictionary Le petit Robert shows little change: 'excellence: bonté, perfection, supériorité' (Rey \& Rey-Debove 1990: 722). Benevolence, perfection, superiority: all appealing to a high ideal and perhaps belonging to another world.

Perfection suggests unattainability and yet a university library search shows us just how commonplace the demand for excellence has become. We find entries on excellence in nursing, teaching, management and business, funding, technology, obstetrics, publishing, engineering, refractive eye surgery, customer care, metal casting, and sales, just to name a few! Excellence appears to be widespread and, like an epidemic, there may be a cost. Does the word risk degradation through excessive or improper use?

The Shorter Oxford English Dictionary on Historical Principles (1973) tells us that the word 'excellence' originates from the Latin 'excellere [meaning to] be eminent, rise, raise'; in English, from 1493 the verb 'excel' meant 'to outdo, surpass' (695). Its more modern definition of excellence is 'The state or fact of excelling; the possession chiefly of good qualities in an unusual degree' (695). How we define and measure those good qualities is a matter for debate and, as we will see, the competitive urge for one to outdo the other, thus make a claim for excellence, has been vigorously embraced. However, when the dictionary entry reveals that the philosopher, David Hume thought Queen Elizabeth the First 'an excellent hypocrite' (696), we are reminded that excellence can have a dark side.

Marketing slogans such as: 'The Pursuit of Excellence will help you discover your intrinsic ability to manifest the life you want' (Excellence Seminars International 2014) and animal trivia: 'Ferrets: The Pursuit of Excellence' (Lewis 2007) suggest that the word 'excellence' has already been so degraded that it has become meaningless. Similarly, it appears that the label 'Centre of Excellence' has been applied indiscriminately across a range of disciplines, including performing arts, medical science, and interactive story telling in the virtual realm (Cavazza et al 2008); the term has even been appropriated to pun a rugby hero [1]. If all these Centres are aiming for excellence then a more honest - and grammatically correct designation would be 'Centre for Excellence', and yet the sheer number of organizations boasting to be one or the other suggests that we are at a point where doing something well is no longer good enough. Do we take their claims of excellence at face value? How do we know they are excellent, or indeed, what sort of excellence is being claimed? 


\section{Indicators of excellence}

A great deal of the literature on excellence in education relates to gifted students and to promoting talent (Heller et al 2000; Tan 2013). Yet, in their Handbook of Expertise and Expert Performance, psychologist K Anders Ericsson and his colleagues (2006) manage to completely avoid any mention of excellence, and when in 2006-7 the Harvard Graduate School of Education was commissioned to consider quality and excellence in arts education in the USA, they discovered a different sort of quality. Their extensive research, involving children and their teachers from kindergarten to year 12, indicated that:

The most important indication of excellence in arts education is the quality of students' learning experiences, not the quality of the artworks they produce. In a very real sense, students' experiences are the primary product, not the artworks they produce. (Seidel et al 2010: 85)

They went on to conclude:

It is perhaps one of the greatest lessons we can offer our students - that the pursuit of quality is both central to the achievement of excellence and a wonderful, challenging, and compelling learning experience in itself. (88)

When we look now at how we define 'excellence in research' in the tertiary education sector we find that something may have been lostbetween the lessons of the school room and the aspirations of the university.

The Department of Human Resources at University of Bristol provides a detailed list of what constitutes excellence, spelling out the criteria for academic promotion:

Excellence in research ... will demonstrate work of originality which has made an observable impact on the subject. It is measured against output and should show a substantial body of work of international (or where appropriate, national) quality. (University of Bristol 2013)

Others devise ever more complex, yet also narrow measures. For example, when the 1994 Group, comprising nineteen UK universities, compared the UK's research strengths with those in other countries they utilised a new measure of research excellence called 'research competencies'. Using co-citation analysis it identifies topics of research that meet the publisher Elsevier's standards of excellence. These standards are 'based on number of publications, number of citations and a measure of novelty' (Wellings \& Winzer 2011: 1). However the report advised that it was not possible to use this measure for humanities research, and because the main concern was 'competency productivity' (8), it included only scientific studies. It found that the UK 'produces more "bang per buck" in producing research excellence' (34) but concluded that funding remained a crucial ingredient. It does not define 'novelty' or how it is measured.

Looking further afield, science and technology researchers, Daniel Vertesy and Stefano Tarantola set out 'to explore the possibility to develop a composite indicator of research excellence in Europe' (Vertesy \& Tarantola 2011: 3). They proposed three theoretical frameworks, incorporating previously identified indicators which:

characterize knowledge production as well as the institutional arrangements and interactions through which research activities take place, and refer to [basic] research actors, industrial innovation actors and societal and political actors. (3)

The results are included here as an example of how the concept of excellence can be highjacked by scientific jargon and narrow-minded statistics. After rigorous analysis the authors found that only one framework was statistically stable. This was the framework where: 
the research excellence composite indicator was computed as the geometric average of 3 pillars: "P1 - genuine excellence of research actors", "P2 - interactions, collaborations" and "P3 - excellence in industrialresearch". (42)

All the indicators of excellence identified and used in this report are quantifiable measures related to the sciences. There is nothing here that considers the arts or humanities in any form. This seems extraordinary given the report was for the European Commission Joint Research Centre at the Institute for the Protection and Security of the Citizen. We suggest that it is a good example of how scientific methods can be used to claim a superior position in the field of research. Nevertheless, the expert comments at the end of the report are worth noting. Robert Tijssen, Professor of Science and Innovation Studies at Leiden University in The Netherlands, writes: "I would replace the term "research excellence" by something more fitting. How about "knowledge creation and utilization"?' (Tijssen qtd in Vertesy \& Tarantola 2012: 59), while Professor Rémi Barré, from the Conservatoire National des Arts et Métiers in Paris notes: 'My regret ... is that the lack of indicators of "engagement of S\&T [Science and Technology] with society" has logically led to the disappearance of this issue as a "pillar"" (Barré qtd in Vertesy \& Tarantola 2012: 58). These comments, from scientists themselves, remind us that statistical rigour is not enough - or perhaps too much - in the pursuit of excellence, and that society's citizens may need more human engagement to feel protected and secure.

Science and medical writer, Annabel McGilvray (2014) reports on the limits of excellence as she considers the unintended consequences of the different ranking measures used by the New Zealand Performance-Based Research Fund and the Australia Research Council to assess (and fund) quality research. She quotes Jonathan Boston, an academic in Public Policy, who helped design the New Zealand system of ranking individual researchers and who now believes that excellence is not just about scholarship. He suggests that young researchers and interdisciplinary research may be better served by giving value to the impact of the research: 'Publishing in Nature is one way of demonstrating excellence in research... Changing the way that a nation drinks water is another way' (S66). The wellintentioned Boston concludes that more government funding or changes to the assessment criteria are necessary if research excellence is to 'keep improving'. The idea of improving on excellence seems absurd if we consider it as an absolute quality - or perfection - but as we will see, there is much in the literature that understands excellence to be a more dynamic process.

The suggestion to value impact has been taken up in the UK via the Research Excellence Framework (REF) but not all are happy with it. University of Sussex Professor of Science and Technology, Ben R Martin (2011) likens it to a Frankenstein monster and suggests that the costs of administering the REF might out-weigh the benefits. London School of Economics Professor of Political Science and PublicPolicy, Patrick Dunleavy (2011) agrees and offers a more transparent, streamlined, and digital solution to assessing academic excellence. However University of Lancaster historian, Professor Derek Sayer considers the REF an insult. Reminiscent of Hume's opinion of Queen Elizabeth, Sayer's book - Rank hypocrisies: the insult of the REF (Sayer 2015) - is scathing of the way the REF works, particularly its focus on the ranking of individual's research outputs. In his review of the book, Ron Johnston, Professor of Geography at the University of Bristol, outlines Sayer's view of the REF's impact on British academic life:

That impact not only reflects the all-embracing evaluation culture, and the consequent league tabling, that the REF represents but also the gaming that occurs in universities seeking to maximise their returns both financial and charismatic. (Johnston 2015)

Academia in Australia is similarly affected. An analysis of the ERA process by University of Melbourne Emeritus Professor Frank Larkins showed that some universities had dramatically improved their ratings over a two year period, causing him to conclude: 'Universities clearly gained experience from the first round and were more strategic in 
their approach to the 2012 ERA exercise' (Larkins 2012: 6). According to University of Queensland academic, Andrew Bonnell, these so-called strategies prove that the ERA is:

doing more harm than good. It is driving intensified managerialism, creating invidious status hierarchies between and within disciplines, and undermining collegiality. Potentially, it may also threaten academic freedom as managers seek to direct staff more and more where to publish, and even not to publish. (Bonnell2014)

The Sydney Morning Herald Science editor, Nicky Phillips reports that competition for scientific research funding is so fierce that a number of questionable practices have emerged; these include researchers conspiring to influence reviewers, and project ideas being stolen and re-branded. In a public health survey, one in five researchers admitted that they formed alliances with others to improve theirchances of a good review in funding applications, a practice one cancer researcher called 'grantsmanship', adding defensively: 'It's not like they're doing anything evil, it's just strategy' (Phillips 2015: 31). However climate researcher, Ben McNeil, warns that this so- called, strategic behaviour reduces the capacity for innovation in research and challenges the clarity we have come to expect: 'Science has become really opaque, especially when it comes to grant funding' (Phillips 2015: 31).

Gaming aside, economists Katharine Rockett and Pierre Régibeau have shown that excellence does not always reproduce itself, especially if the tool of measurement is metrics. They explain:

We build an economics department entirely composed of Nobel Prize winners and evaluate it using standard research assessment metrics. Performing the same evaluation on existing departments, we find that the rating of our Nobel Prize department does not stand out from other good departments. Compared to recent research evaluations, our Nobel Prize department's ranking is less stable. (Rockett \& Régibeau 2014)

While much of the literature regarding measurement is concerned with the sciences, Professor of Higher Education Studies at University College London, Peter Scott addresses the three main tools for assessing excellence in the humanities and social sciences - 'peer review', where the work is subjectively evaluated by others who have similar competence to the person/s who produced the work; 'metrics', where the work is assessed using quantitative measures such as the number and variety of citations, or where the work is published in a particular journal which is itself ranked against other journals; and 'performance indicators', another form of metric which is a measurable value that demonstrates how effectively a person, department, or faculty is achieving (subjectively) set objectives which often include the afore-mentioned 'metrics'. Scott argues that decisions to use one or the other are 'not simply technical but also reflect underlying value systems' (Scott 2015: 118). His view is that excellence may be better served by employing all three (129). He identifies the 'major elements in the current definition of excellence in research - outputs; methodologies; sustainability; and relevance or applicability' (121) and signals that:

there is an emerging tension between methodologies for assessing excellence, which are tending to become more urgent and more prescriptive, and concepts of excellence, which are becoming more open, more fluid and more contested. (129)

Can this tension be resolved when assessment is concerned only with an end product?

Leaning towards the notion of excellence as a process, Onora O'Neill, Cambridge

philosophy professor, and member of the House of Lords, enlists the help of Aristotle. She argues that, while excellence is 'a noble aim ... there are many excellences' (O'Neill 2015: 114 ) and not all arrive at success; neither does success presume excellence. She notes that success is a 'positional good'(114) as in university league tables, but excellence is possible in all universities. She takes aim at inefficient and easily manipulated accountability 
measures which get in the way of excellence: 'At their worst, they create perverse incentives. Even when they do not do so, they divert attention from excellence to comparative success, defined in narrow ways' (115).

Others are more concerned with the nurture of excellence than with its measurement. As psychology professors, David Lubinski and Camilla Benbow noted, for most of us, 'Excellence takes time' (Lubinski \& Benbow 2000). With a focus on the gifted student, Lubinski and Benbow suggested that, by using a combination of theory of work concepts and psychometric methods, an existing talent can be developed further but 'positive psychological experiences are required to provide the right environment for eminence to emerge' and that this 'takes approximately 10 years of concentrated effort' (ibid). To illustrate this point they relate the story of Ignacy Jan Paderewski, the great Polish pianist, who, when told he was a genius, responded: 'Yes, and before that I was a drudge' (ibid).

Psychology undergraduate, Silvia Monteiro and her colleagues (2014) expand on this with their study of engineering students. They conclude that excellence is a dynamic process not a state:

It seems to us that excellence cannot be conceptualized as fully completed at a specific development stage, but rather as a process on continuous nurturance and evolution. According to this perspective, becoming excellent seems a more appropriate term than being excellent, which would remit us to a dichotomous state of to be or not to be excellent. (Monteiro et al 2014, authors' emphasis)

They go on to advise that:

it does not seem relevant to look for "a formula of excellence", as if excellence would represent an ended and confined product reduced to a sum of isolated factors. (Monteiro et al 2014)

Excellence has long been used as a concept in psychology. The so-called father of American psychology, William James (1890) believed that excellence in education could be achieved when wandering minds learned how to be more focused. In a similar vein, and one hundred years later, the Hungarian psychologist, Mihaly Csíkszentmihalyi (1991) developed the notion of 'flow' to describe what happens when our intention and emotions are completely absorbed in a task in a positive and invigorated way. He believed that when weare fully focused, we can achieve extraordinary things. Today one might call this 'mindfulness'.

Positive psychologists such as Csíkszentmihalyi perceive excellence as a way of being, an inner experience, while many mainstream psychologists are more interested in physical measurement and the gathering of empirical evidence. This preoccupation with measurement has a long history in psychology, sport and education, especially when assessing intelligence and achievement (Giordano 2005). While this paper does not wish to conflate excellence with intelligence, others have, and do. The process of evaluating people who excel in intelligence has its beginnings with the French psychologist, Alfred Binet (1916) and the American psychologist, David Wechsler (1939), who developed intelligence tests that are still used today. However, there is still no consensus in regards to what intelligence actually is and how it should be measured, if at all (Weiten 2010). There is also the contentious question of whether excellence is innate or learned (Howe, Davidson \& Sloboda 1998). The uncertainty regarding both its provenance and its composition has led the New York education researcher, Professor Norman Eng (2015) to caution that excellence should not be reduced to a quantifiable, observable construct; we simply cannot say with certainty that people have more or less excellence in knowledge.

\section{Is there a formula for research?}

We have seen that a formula for excellence remains elusive, yet we keep looking for excellence itself, and wonder if research will be more forthcoming. We start our search 
with two, very different definitions that speak to the problem at hand: Is 'excellence in research' a product or a process?

Excellence for Research in Australia, administered by the Australian Research Council, defines research as:

the creation of new knowledge and/or the use of existing knowledge

in a new and creative way so as to generate new concepts,

methodologies, inventions and understandings. (ERA 2015: 12)

Yet only forty-odd years ago The Shorter Oxford English Dictionary on Historical Principles (1973) gave us this definition: '[research is] a course of critical or scientific inquiry, an investigation' (1804). The emphasis here is on the process rather than the product; research as an action, not an outcome. One wonders what becomes of the dynamic quality of research - the dramatic push and pull of trial and error, of exploration, of taking risks - if it is always cast as a static noun. One wonders too, how and why this shift in emphasis occurred.

There is nothing in either definition to suggest that new scientific knowledge is superior to knowledge gained through the arts or that a scientific inquiry trumps a critical investigation into any of the arts. However, as we have seen from our survey of measuring excellence, it is easy to imagine that contemporary society generally, and research funding bodies in particular, might favour the supposed certainty of science (especially if it is measurable) over the necessary ambiguity of the arts. Significant efforts to address this imbalance were led by a scientist, Professor Margaret Sheil, in her role as Chief Executive Officer of the Australian Research Council. Flinders University academic, Julian Meyrick explains that the new assessment categories that Sheil championed for ERA made way for the creative arts to finally 'have a seat at the research table' in 2015 (Meyrick 2014). While this has been hailed as progress and has 'promoted a greater degree of cross-disciplinary awareness', Meyrick warns against premature celebration, pointing to the UK experience where, despite substantial changes to assessment categories, outcomes continue to be quantified and quantifiable.

Data may well be 'the new bunkum' (Meyrick 2014) but it is powerful bunkum - a dictatorship that deepens the perceived gulf between art and science and, counterproductively, limits their potential impact. How did this apparent dichotomy come about and is art and science really so black and white? These are questions for the philosophers, not data processors. While a comprehensive examination of art and science throughout history is beyond the scope of this paper [2], a brief look at certain key moments may provoke new thoughts and suggest some answers.

\section{Art and Science}

In the times when myths explained the world and its ways, and before science even had a name, Apollo and Dionysus, the sons of Zeus were known as the gods of the arts. Apollo was the god of reason and rationality while Dionysus stood for irrationality and chaos. Then, in ancient and medieval times, the word 'science' tended to describe any systematic body of knowledge, ranging from theology to mathematics. The methods used to obtain this knowledge depended on beliefs at the time about what could possibly be known (Craig 2005: 946-7). Plato divided knowledge into two categories: sensory experience, which he dismissed as mere opinion, and genuine knowledge obtained by the pure intellectual work of reason. Aristotle, on the other hand, believed that we use our senses to develop knowledge by means of deduction, and thus began a philosophy of science and the scientific method (Craig 2005: 948).

According to the American philosopher and psychologist, John Dewey it was Galileo who first 'expressed the changed temper that was coming over the world; the transfer of interest from the permanent to the changing' (Dewey 1909: 182) and it was Galileo who 'consciously formulated for the first time the principle of objectivity in science' (Magee 
1998: 64) when he insisted that the observer's personal sensory experience must not be part of the recorded observation. Because Galileo's discoveries did not fit with Church dogma both he and his research came under fire. When he successfully argued that his work was specialized, and therefore could not be judged by those who did not understand or perform it, he was, for a time, able to keep the religious authorities out of his scientific business. In this way, Galileo effectively divorced his science from other, less objective influences, particularly the myth and mystery that Church- sponsored art represented. However, Esther Theiler an early modern Renaissance scholar, reminds us that Galileo himself was a more nuanced character - an artist and writer as well as a scientist (Theiler 2015). He studied drawing and created beautiful pictures of the moon he saw through his telescope. His friend, the painter Il Cigoli, was so inspired by Galileo's descriptions of the craters on the moon that he painted them on his fresco of Mary on the ceiling of Santa Maria Maggiore in Rome. Galileo also published his scientific findings as works of literature, in the form of dialogues, where his use of persuasive rhetoric to inform and educate others of his scientific discoveries cleverly minimised the risk of offending the authorities.

The eighteenth-century Enlightenment introduced a new brand of reason. This was not the ready-made, intellectual reason of Plato or the deductive reasoning of Aristotle, but Isaac Newton's method of analysis, one which cleared the way for all enlightened thinkers: 'the real power of reason is to be found not in the possession but in the acquisition of truth' (Cassirer 1951: 14). Analysis became the universal instrument for thinking generally - not only in physical or mathematical inquiry - and a symbol of progress. In his Traité de métaphysique Voltaire pronounced: 'When we cannot utilise the compass of mathematics or the torch of experience and physics, it is certain that we cannot take a single step forward' (see Cassirer 1951: 12).

Analysis was also what drove French philosopher, Denis Diderot. His aim for his extraordinary Encyclopédie,ou dictionnaire raisonné des sciences, des arts et des métiers (Encyclopaedia, or a Systematic Dictionary of the Sciences, Arts, and Crafts)was 'pour changer lafaçon commune de penser', to change the common way of thinking (Cassirer 1951: 14). The Encyclopédie embodied and symbolised new thought of the French Enlightenment, with a liberal-mindedness that managed to upset both church and state. Emphasizing secularknowledge, Diderot reminds us that any distinction between the arts and sciences is ours to make:

In pursuit of his needs, luxury, amusement, satisfaction of curiosity, or other objectives, man applied hisindustriousness to the products of nature and thus created the arts and sciences. (Diderot 1751)

The Encyclopédie itself is a product of two very different minds: Diderot, the philosopher, writer, and art critic, and Jean le Rond d'Alembert, a mathematician who understood the strength of their inter-dependence:

If one reflects somewhat upon the connection that discoveries have with one another, it is readily apparent that the sciences and the arts are mutually supporting, and that consequently there is a chain that binds them together. (d'Alembert 1751)

Another who understood this chain was the French philosopher, Jean-Jacques Rousseau, one of the many contributors to the Encyclopédie. For all his contradictions, Rousseau

repeatedly used the phrase "les sciences et les arts" as though the two terms were a single entity [and while he] took his distance from the culture of the Encyclopédie, it is not because he was against science or ignorant of it... The target of his condemnation was not sciences themselves but the societal misuses of the sciences and the arts for individual interests and profit. (Grace \& Kelly 2012: 75)

Around the beginning of the nineteenth century, the growing interest in secular (scientific) knowledge and self-improvement created not only a challenge to religious piety, but also 
some anxiety 'that calculation and measurement generally might be displacing cultivation and compassion' (Colloni 1993: xi). The revolutionary ideas of German philosopher Friedrich Nietzsche sought to overcome this anxiety by 'viewing science through the optic of the artist, and art through the optic of life' (Nietzsche 1872: 5); Nietzsche insisted that the opposition and interdependence of the Apollonian and Dionysian drives enables each to 'reach its goals through the other' (Smith 2000: xxxiii). However, as an academic work, his Birth of Tragedy was attacked for its 'inaccuracy, distortion, lack of objectivity, and its attack on contemporary research methods' (Smith 2000: xxx). The same criticism could be levelled at arts-based research today.

If we follow Nietzsche's suggestion, and if we allow ourselves to look, we will find numerous examples of art and science working through each other's optic, creatively inhabiting each other's space. Raphael the artist, through his skilful craftsmanship, gives us the School of Athens, a majestic piece depicting not only the Plato/Aristotle divide (Herman 2013) but a range of representations of who's who in the artistic and scientific thought of the ancient world. Rose-Lynne Fisher's aesthetically beautiful photographs that microscopically examine a human tear blur art/science boundaries (Stromberg 2013), and Thorpe reminds us that 'Beckett's exhortation to artists to "Try again. Fail again. Fail better" is compatible with the scientists' empirical creed of trial and error' (Thorpe 2012). The physician and writer, Karen Hitchcock believes that 'Prognostication is an art and a moral judgement dressed up in a scientific coat' (Hitchcock 2015: 16); Carroll Dunham, the artist, maintains that 'Being an artist is a form of radical entrepreneurship' (Thornton 2014: 228); and Perry Hoberman, a media, installation, and performance artist who works with a wide range of technologies, insists: 'as an artist, I think my job is to interrogate these technologies, not just to use them' (Galison \& Jones 2014: epigraph).

In Transfiguring the Arts and Sciences (2013) the American professor of English, Jon Klancher offers an explanation for the spread of 'new arts-and-sciences institutions' that focused on the charismatic lecturing of the poet Samuel Taylor Coleridge and his friend, the chemistry professor, Humphrey Davy at venues such as the Royal Institution, circa 1810. Their growth, argues Klancher, represents a phase in the development of the knowledge economy prior to the utilitarian division of labour identified with the modern disciplines of art and science. Klancher identifies Thomas de Quincey's 1823 distinction between a literature of power and a literature of knowledge, based on the idea of 'improvement', as the maul that splintered the discourse of 'arts and sciences' (Klancher 2013). Jon Mee places these transformations in the context of the 'industrial enlightenment', a phenomenon which, he claims, preceded Klancher's institutions and continued to exercise a powerful influence in Britain - and as far away as Cape Town and Sydney - in the early decades of the nineteenth century, through literary and philosophical societies that began in Manchester in 1781. He shows that the quest for 'improvement' in these societies was not solely focussed on the science-technology interface, but was also self-consciously invested in 'physics and the belles lettres' (Mee 2015); this allowed the societies to proliferate via self-organising provincial networks of correspondence and discussion, extending beyond the traditional centres of power.

France experienced similar correspondances. John Tresch, University of Pennsylvania Associate Professor of History and Sociology of Science, argues that French scientists and artists used the new technologies of the industrial age to forge a path between 'hopeless romanticism and soulless mechanism, making technology and science instruments of inspiration and even salvation' (Tresch 2012: xi). Focusing on Paris in the 1820s, 30s and $40 \mathrm{~s}$, he suggests that 'romantic machines' like steam engines and photography allowed a space for 'human thoughts, feelings, and intentions' to play a role in the new understandings of how the world worked. This was in stark contrast to the 'detached, impersonal, and emotionless objectivity' (xi) of scientific thought in the seventeenth century.

Tresch goes on to explain how their defeat at Waterloo proved to the French that their 'excellence in mathematics and engineering' (Tresch 2012: 7) was not enough against the mechanical superiority of the industrialised English. He suggests that this may have started 
the politicisation of science, and notes that ' $[\mathrm{t}]$ he close connection between claims of scientific decline and the fear of military defeat ... should force us to ask just what we mean by scientific progress and to ask how it ought to be measured' (18).

The word 'scientist' did not appear in English until 1834 when, in the search for a generic term [3] for those engaged in the study of the knowledge of the material world, it was 'proposed that, by analogy with artist they might form scientist' (Whewell 1962 [1834]: 59). Nevertheless it took many years of impassioned and often entertaining argument (Ross 1962) before the term was accepted; now, of course its meaning has enlarged, and, like the word 'artist', continues its socio-cultural evolution.

Diderot and d'Alembert might argue that we are born, not made, to be one or the other:

Imagination acts no less in a geometer who creates than in a poet who invents. It is true that they operate differently on their object. The first shears it down and analyzes it, the second puts it together and embellishes it. It is true, further, that these different ways of operating stem from different sorts of minds, and for this reason the talents of a great geometer and those of a great poet will perhaps never be found together. But whether or not they are mutually exclusive, they have no right to hold one another in contempt. (d'Alembert 1751)

Our poet and physicist would surely agree.

Two hundred years later, and in the context of a culture that, one could argue, tended to be narrow in its outlook, the English physical chemist and novelist, CP Snow (1993) proved himself incapable of entertaining d'Alembert's progressive inclusiveness. In 1959, Snow's (in)famous public lecture, 'The Two Cultures and the Scientific Revolution', positioned literary intellectuals and scientists as polar opposites. A self-professed scientist by training and writer by vocation (Snow 1993: 1), Snow's championing of scientific progress, while simultaneously denigrating literary traditions, may have been as much about inequalities in the English class system, and his own place in it, as it was about giving science the place he believed it deserved in the education system at that time.

This glimpse of history - where art and science began as one, only to be separated, linked, divided again, and manipulated so that each is presented as the antithesis of the otherhighlights the power and prejudice of cultural context. It reminds us to ask, and to keep asking:

What are the conditions under which objects become visible in culture, and in what manner are such visibilities characterized as "science" or "art"? ...The focus on the two as discrete products ... ignores the commonalities in the practices that produce them. Both are regimes of knowledge, embedded in, but also constitutive of, the broader cultures they inhabit. (Galison \& Jones 2014: 1-2)

While Snow's description of two cultures magnified a divisiveness that now, nearly fifty years later, threatens the future of the humanities [4], the English literary critic and academic, Stefan Colloni, sounding more like d'Alembert, calls for a 'common culture' (Colloni 1993: lvi), arguing that:

we need to encourage the growth of the intellectual equivalent of bilingualism, a capacity not only to exercise the language of our respective specialisms, but also to attend to, learn from, and eventually contribute to, wider cultural conversations. (Colloni 1993: lvii)

The British poet, Ruth Padel would not be surprised to see our poet and physicist together in the garden. She argues that poetry and science already have much in common, sharing modesty and uncertainty as they 'fertilise each other'. Each try to get at a 'universal' by starting with 'the particular' and metaphor is 'crucial' for both: 'A new metaphor is a new mapping of the world' (Padel 2011). 
Research is full of potential new metaphors that help to map our world but increasing demands for excellence threaten to render themuseless. Like the map in the story by Argentinian writer, Jorge Luis Borges [5], we risk ending up with something that offers nothing new or meaningful; worse, we risk bequeathing a map that leaves the paths to knowledge in 'Tattered Ruins' (Borges 1999: 325).

Perhaps what we need instead are maps:

superimposed in such a way that each map finds itself modified in the following map, rather than finding its origin in the preceding one: from one map to the next, it is not a matter of searching for an origin, but of evaluating displacements. (Deleuze 1997: 63)

\section{Conclusion}

We set out to make sense of the rules of the game: to understand research, excellence, and excellence in research. We conclude that measuring excellence in research is an impossible task. It is also unnecessary. Excellence is a process: it's how you play the game. Research that is concerned only with winning is unlikely to engage the hearts and minds of large numbers of higher education students. If we are seriously interested in new knowledge, research needs to be more than just 'a show of knowledgeableness' (Leavis 1962). The chain that binds the Arts and Sciences is us; if we are to grow a strong, healthy society, one that is not too anxious to risk exploration of all aspects of our lives and minds, and of the world we inhabit, we must reject the partiality that persists in 'the two cultures' and instead, promote and value research in all its variety, regardless of its measure.

This story of excellence, of artists, scientists, research, and meaning has no end. The poet and the physicist make use of different metaphors but they map the same world in their search for a particular and universal quality which can be neither weighed nor measured. Some call it excellence; others call it truth. We do not pretend to have the answers but we do need to keep asking the questions: questions about how our work is evaluated, valued, and funded, and, most importantly, how students learn to play a game that is worth playing, creatively.

\section{Epilogue}

(Ten years later)

The poet and the physicist go to dinner in the Marais. Now a grandfather, the physicist shows the poet photos of a plump cherubcavorting among the rainbow kites his parents (the cherub's) make and fly all over the world.

Afterwards, mildly drunk, they walk through the cold, clear night in search of a jazz gig in the Charonne area, just within cooee of the Boulevard Voltaire.

So, what was it you were jotting down in your wee notebook all these years back?

Oh! Nothing in particular. Ideas, phone numbers,

equations, appointments, directions... I see.

You seem surprised.

I thought it was more purposeful.

I guess I know where you are coming from. But a lot of what I do is trial and error. Like you, I guess. The only difference is: I've got to validate my findings. You don't. If you make a mistake, that can be a breakthrough, an innovation. 
But there is a convergence.

Yes, but if my maths don't add up, the project is screwed.

Hey, I can't remember ever passing this

construction site. Are we lost? Maybe.

Have you got a map?

We don't need one. Keep walking until we get to rue du

Chemin Vert and we'll be right. Eruption of uncontrollable

laughter.

\section{Notes}

[1] A story about a talented and much-loved, self-deprecating Scottish rugby player, Jim Renwick, who played in the centre (Barnes 2013). return to text

[2] A more comprehensive overview of the rise and fall of the art/science relationship can be found in the introduction to Picturing science, producing art, by Harvard Professor of History of Science and of Physics, Peter Galison, and Art History academic, Carolina Jones (Galison \& Jones 2014). return to text

[3] The German term 'natur-forscher' was rejected because it could be translated as 'nature- poker' or 'nature- peeper'! (Ross 1962: 72). return to text

[4] Preston reports that the changes to universities in Britain amount to 'war against the humanities' (Preston 2015). return to text

[5] Borges' short story is only one paragraph long:

In that Empire, the Art of Cartography attained such Perfection that the map of a single Province occupied the entirety of a City, and the map of the Empire, the Entirety of a Province. In time, those Unconscionable Maps no longer satisfied, and the Cartographers Guilds struck a Map of the Empire whose size was that of the Empire, and which coincided point for point with it. The following Generations, who were not so fond of the Study of Cartography as their Forebears had been, saw that the vast Map was Useless, and not without some Pitilessness was it, that they delivered it up to the Inclemencies of Sun and Winters. In the Deserts of the West, still today, there are Tattered Ruins of that Map, inhabited by Animals and Beggars; in all the Land there is no other Relic of the Disciplines of Geography. (Borges 1999: 325) return to text

\section{Works cited}

ACARA 2013 ACARA: Australian Curruculum, Assessment and reporting Authority: www.acara.edu.au/ (accessed 27 October 2015)return to text

Andrews, EA 1879 A Latin Dictionary, founded on Andrew's edition of Freund's Latin Dictionary, revised, enlarged, and in great partrewritten by Charlton T Lewis and Charles Short, Clarendon Press, Oxford return to text

Barnes, D 2013 Centre of Excellence: The Jim Renwick Story, e-book:

http://SWIN.eblib.com.au/patron/FullRecord.aspx?p=1184929(accessed 7 March 2015) return to text

Binet, A 1916 'New methods for the diagnosis of the intellectual level of subnormals', trans ES Kite, The development of intelligence in children, Publications of the Training School at Vineland, Vineland, NJ. Originally published in 1905 in L'Année Psychologique 12: 191-244 return to text

Bonnell, A 2014 'Two Rounds Enough: ERA Does More Harm than Good', The Australian Higher Education Supplement (22 October):http://www.theaustralian.com.au/higher-education/two-rounds-enoughera-does-more-harm-than-good/story-e6frgcjx-1227097532275 (accessed 23 September 2015) return to text 
Borges, JL 1999 'On Exactitude in Science', Collected Fictions, trans A Hurley, Penguin Books, New York: 325 return to text

Cassirer, E 1951 The philosophy of the enlightenment, Princeton University Press, Princeton NJ return to text

Cavazza, M, S Donikian, M Christie, U Spierling, N Szilas, P Vorderer, T Hartmann, C Klimmt, E André, R Champagnat, P Petta \& P Olivier 2008 'The IRIS Network of Excellence: Integrating Research in Interactive Storytelling', Interactive Storytelling, Lecture notes in computer science 5334, 14-19: http://link.springer.com/chapter/10.1007/978-3-540-89454-4_3 (accessed 16 March 2015) return to text

Colloni, S 1993 'Introduction', in CP Snow, The two cultures, Cambridge University Press, Cambridge, eBook Academic Collection,EBSCOhost (accessed 26 September 2015) return to text

Craig, E (ed) 2005 The shorter Routledge encyclopedia of philosophy, Routledge, London return to text

Csikszentmihalyi, M 1991 Flow: The Psychology of Optimal Experience, Harper Collins, New York return to text

D’Alembert, JLR 2009 [1751] 'Preliminary Discourse', The Encyclopedia of Diderot \& d'Alembert Collaborative TranslationProject,trans RN Schwab \& WE Rex, Michigan Publishing, University of Michigan Library, Ann Arbor: http://hdl.handle.net/2027/spo.did2222.0001.083 (accessed 4 May 2015) return to text

Deleuze, G 1997 'What Children Say', Essays: Critical and Clinical, trans DW Smith \& MA Greco, University of Minnesota Press, Minneapolis return to text

Dewey, J 2005 [1909] 'The influence of Darwinism on philosophy', in JM Capps \& D Capps (eds) James and Dewey on belief and experience, University of Illinois Press, Urbana: 182: eBook Academic Collection, EBSCOhost (accessed 15 September 2015) return totext

Diderot, D (ascribed by J Proust) 2003 [1751] 'Art', The Encyclopedia of Diderot \& d'Alembert Collaborative Translation Project, trans NS Hoyt \& T Cassirer, Michigan Publishing, University of Michigan Library, Ann Arbor. Originally published as 'Art', Encyclopédie ouDictionnaire raisonné des sciences, des arts et des métiers 1, Paris: 713-717: http://quod.lib.umich.edu/d/did/ (accessed 20 April 2015) return to text

Dunleavy, P 2011 The Impact Blog, London School of Economics and Political Science: http://blogs.lse.ac.uk/impactofsocialsciences/2011/06/10/ref-alternative-harzing-google-scholar/ (accessed 9 March 2015) return to text

Eng, N 2015 'Excellence redefined for the 21st Century', Society journal 52: 237-241 return to text

ERA 2015 'Submission guidelines':

http://www.arc.gov.au/pdf/ERA15/ERA\%202015\%20Submission\%20Guidelines.pdf (accessed 19March 2015) return to text

Ericsson, KA, N Charness, P Feltovich \& RR Hoffman (eds) 2006 Cambridge handbook of expertise and expert performance, Cambridge University Press, Cambridge:

http://search.credoreference.com.ezproxy.lib.swin.edu.au/content/title/cupexpert (accessed 19March 2015) return to text

Excellence Seminars International 2014 'The Pursuit of Excellence', Excellence Seminars International: http://www.excellenceseminars.com/programs/excellence-series/pursuit-of-excellence/ (accessed 11 March 2015) return to text

Galison, P \& CA Jones (eds) 2014 Picturing science, producing art, Routledge, London: EBL ebook library (accessed 17 March 2015)return to text

Giordano, G 2005 How testing came to dominate American schools: The history of educational assessment, Peter Lang, New Yorkreturn to text

Grace, E \& C Kelly 2012 The challenge of Rousseau, Cambridge University Press, Cambridge return to text Heller, KA, FJ Mönks, RJ Sternberg \& RF Subotnik (eds) 2000 International handbook of giftedness and talents, Pergamon, New Yorkreturn to text

Herman, A 2013 The cave and the light, Random House, New York return to text

Hitchcock, K 2015 'Dear Life. On caring for the elderly', The Quarterly Essay 57 (March): 1-78 return to text

Hoberman, P 2011 Perry Hoberman: http://www.perryhoberman.com/ (accessed 28

June 2015) 
Howe, MJA, JW Davidson \& JA Sloboda 1998 'Innate talents: Reality or myth?', Behavioral and Brain Sciences 21: 399-442 return totext

James, W 1962 [1890] The Principles of Psychology, Smith, New York return to text

Johnston, R 2015 The Impact Blog, London School of Economics and Political Science:

http://blogs.lse.ac.uk/impactofsocialsciences/2015/03/08/book-reviewrank-hypocrisies-the-insult-of-the-ref/ (accessed 19 March 2015)

return to text

Klancher, J 2013 Transfiguring the Arts and Sciences: Knowledge and Cultural Institutions in the Romantic Age, Cambridge UniversityPress, Cambridge return to text

Larkins, FP 2012 ERA 2012 (Part 1): University responses and performances compared with ERA 2010, LH Martin Institute for tertiary education, leadership and management:

http://www.lhmartininstitute.edu.au/userfiles/files/Blog/FLarkins_HE\%20Research\%20Policy\%20Analysis_ER A2012_pt1_Feb2013.pdf (accessed 23 September 2015) return to text

Leavis, FR 1962 'Two Cultures? The Significance of C.P. Snow', Spectator (9 March), in Stefan Collini 'Introduction' to CP Snow, Thetwo cultures, Cambridge University Press, Cambridge, eBook Academic Collection, EBSCOhost (accessed 27 June 2015) return to text

Lewis, M 2007 Ferrets: The pursuit of excellence (DVD), USA:

http://www.shoppbs.org/product/index.jsp?productId=2766730(accessed 16 March 2015) return to text

Lubinski, D \& CP Benbow 2000 'States of excellence', American Psychologist, vol. 55, no. 1, 137-150, APA PsycNET, (accessed 3 March 2015) return to text

Lucas, L 2006 The Research Game in Academic Life, McGraw-Hill Education, Maidenhead, Berkshire, eBook Academic Collection,EBSCOhost, (accessed 27 September 2015) return to text

Magee, B 1998 The story of philosophy, DK publishing, New York return to text

Martin, BR 2011 'The Research Excellence Framework and the 'impact agenda': are we creating a Frankenstein monster?', ResearchEvaluation 20, 3: 247-254:

http://rev.oxfordjournals.org/content/20/3/247.abstract (accessed 9 March 2015) return to text

McGilvray, A 2014 'Research assessment: The limits of excellence', Nature 511: S64-S66:

http://www.nature.com.ezproxy.lib.swin.edu.au/nature/journal/v511/n7510_supp/full/511S64a.html (accessed 7 March 2015) return totext

Mee, J 2015 'Transpennine Enlightenment: Power and Knowledge in the Romantic Period, 1781-1830', Paper given at the Re-ReadingRomanticism: Imagination, Emotion, Nature and Things conference, University of Melbourne, 23 July return to text

Meyrick, J 2014 'Measure for measure: the creative arts and the "impact agenda"', The Conversation, (13 October): http://theconversation.com/measure-for-measure-the-creative-arts-and-the-impact-agenda-32740 (accessed 25 September 2015) return totext

Monteiro, S, LS Almeida, RM Vasconcelos, J Cruz \& A Fernando 2014 'Be(com)ing an excellent student: a qualitative study with engineering undergraduates', High Ability Studies 25, 2: 169-186: Routledge Web of Science (accessed 3 March 2015) return to text

Nietzsche, FW 1872 The birth of tragedy, Oxford: Oxford University Press: eBook Collection EBSCOhost (accessed 19 April 2015)return to text

O’Neill, O 2015 'Integrity and quality in universities: accountability, excellence and success', Humanities 4: 109-117:http://www.mdpi.com/2076-0787/4/1/109 (accessed 17 March 2015) return to text

Padel, R 2011 'The science of poetry, the poetry of science', The Guardian (10 December): http://www.theguardian.com/books/2011/dec/09/ruth-padel-science-poetry(accessed 23 August 2015) return to text

Phillips, N 2015 'Scientists resort to "gaming” the system as funds dry up', The Age Insight (11 April): 31 return to textPreston, A 2015 'The war against humanities at Britain's universities', The Guardian (29 March):

http://www.theguardian.com/education/2015/mar/29/war-against-humanities-at-britains-universities (accessed 12 May 2015) return to text 
Rockett, K \& \& PM Regibeau 2014 'A Tale of Two Metrics: Research Assessment vs Recognised Excellence', Social Science Research Network (17 December): http://ssrn.com/abstract=2539549 or http://dx.doi.org/10.2139/ssrn.2539549 (accessed 9 March 2015) return to text

Ross, S 1962 'Scientist: The story of a word', Annals of Science18, 2: 72: Taylor \& Francis online (accessed 27 June 2015) return to text

Sayer, D 2015 Rank Hypocrisies: the Insult of the REF, SAGE, Thousand Oaks CA, (accessed 25 August 2015) return to text

Schuster, MA 2010 'Excellence in research: threats from all directions', Journal of adolescent health 46, 2 (February): 110-112: ScienceDirect (accessed 7 March 2015)

Scott, P 2015 'Clashing concepts and methods: Assessing excellence in the Humanities and Social Sciences', Humanities 4: 118-130:http://www.mdpi.com/2076-0787/4/1/118 (accessed 11 March 2015) return to text

Seidel, S, S Tishman, E Winner, L Hetland \& P Palmer 2010 The Qualities of Quality: Understanding Excellence in Arts Education,Project Zero,Harvard Graduate School of Education, Cambridge MA: $\mathrm{http}$ //www.wallacefoundation.org/knowledge- center/arts-education/arts-classroominstruction/Documents/Understanding-Excellence-in-Arts-Education.pdf (accessed 4 March 2015)return to text

Smith, D 2000 'Introduction', The birth of tragedy, Oxford University Press, Oxford: eBook Collection EBSCOhost (accessed 19 April 2015) return to text

Snow, CP 1959 The Two Cultures, Cambridge University Press, London: eBook Collection, EBSCOhost (accessed 27 June 2015) return to text

Stromberg, J 2013 'The microscopic structures of dried human tears', Smithsonian.com: http://www.smithsonianmag.com/science-nature/the-microscopic-structures-of-dried-human-tears180947766/?no-ist (accessed 9 march 2015) return to text

Tan, AG (ed) 2013 Creativity, Talent and Excellence: SpringerLink, Springer eBooks (accessed 4 March 2015) return to text

The shorter Oxford English dictionary on historical principles 1973, Oxford University Press, Oxford return to text

Theiler, E 2015 Personal communication with the authors return to text

Thornton, S 201433 artists in 3 acts, Granta, London return to text

Thorpe, V 2012 'A new discovery for science and art: the cultural divide is all in the mind', The Guardian (25 November): http://www.theguardian.com/culture/2012/nov/24/science-art-twocultures (accessed 9 March 2015) return to text

Tresch, J 2012 The romantic machine: Utopian science and technology after Napoleon, University of Chicago Press, Chicago: EBLEbook library (accessed 23 September 2015) return to text

University of Bristol 2013 'Defining Excellence - Guidance on the application of the promotion criteria', University of Bristol Human Resources: http://www.bristol.ac.uk/hr/policies/promotion/guidanceexcellence.html (accessed 9 March 2015) return to text

Vertesy, D \& S Tarantola 2012 Composite indicators of research excellence, JRC Scientific and Policy reports, European Commission:

http://publications.jrc.ec.europa.eu/repository/bitstream/JRC72592/reqno_jrc72592_deliverable3_res_exc.pd f[1].pdf (accessed 28 October 2015) return to text

Wechsler, D 1939 The measurement of adult intelligence, Williams \& Wilkins, Baltimore return to text

Weiten, W 2010 Psychology: Themes and variations, Wadsworth Cengage Learning, South Melbourne Vic return to text Wellings, P \& R Winzer 2011 Mapping research excellence: exploring the links between research excellence and research funding policy, A report from the 1994 Group:

http://www.snowballmetrics.com/wpcontent/uploads/110915_MappingResearchExcellence_1.pdf(accessed 9 March 2015) return to text

Whewell, W 1962 [1834] The Quarterly Review 51, 59, in Sydney Ross, 'Scientist: The story of a word', Annals of Science 18, 2: 72: Taylor \& Francis online (accessed 27 June 2015) return to text 
Dominique Hecq is Associate Professor in Writing at Swinburne. Also a creative writer, she has a background in literary studies, psychoanalysis and translation. Recent papers have contributed to redefining a poetics suited to creative writing research that makes use of psychoanalytical concepts. Towards a Poetics of Creative Writing (2015) is her latest book.

Christine Hill is a midwife and perinatal psychotherapist in private practice. She also works as a volunteer with infants and their families in immigration detention. Her background includes French and Spanish language, poetry, and theatre studies, and psychoanalytic studies. Her PhD thesis, 'Playing with reality: representing the baby', was nominated for Swinburne University's best thesis 2014.

Associate Professor Stephen Theiler has been teaching at Swinburne since 1996. At present he teaches counselling in the Postgraduate area and supervises 4th year, Masters and DPsych and PhD students in their research and clinical work. His teaching achievements include National Carrick Citation for Outstanding Contributions to Student Learning and Vice-Chancellor Excellent Teaching Awards. He is a member of the Australian Psychological Society and is a counselling and clinical psychologist.

\section{TEXT}

Vol 19 No 2 October 2015

http://www.textjournal.com.au

General Editor: Nigel Krauth. Editors: Kevin Brophy \& Enza

Gandolfo

text@textjournal.com.au 